\title{
Development of Accounting Research in the Field of Auditing: Meta Analysis
}

\author{
Mohammad Faris ", Arsono Laksmana \\ Study Program on Master of Accounting, Faculty of Economics and Business, Airlangga University, Surabaya \\ *Corresponding Author: Mohammad Faris, Study Program on Master of Accounting, Faculty of \\ Economics and Business, Airlangga University, Surabaya
}

\begin{abstract}
This research is intended to describe the development of research related to the quality of audit since the year 1981 till 2018. It applies the 'meta analysis method' and the audit quality becomes the unit of analysis in this research.

Data collecting is conducted by using the documentation technique, namely by collecting articles related to the audit quality. Outputs of this research conducted since the year 1981 until 2018 indicate that there is a phenomena confirming that development of research related to audit in general and to the audit quality in particular has a very close relation with the development and dynamics in community, and even it has a relation pattern not only placing the audit research as a pattern of movements and activities in economy, social, political and cultural affairs in community. This can be seen from the indicators on the establishment of audit quality getting more and more advanced from year to year as well as the difference on every output of research conducted with the same indicators.
\end{abstract}

Keywords: Audit Quality, Measurement Indicators, Meta Analysis

\section{INTRODUCTION}

Behavioral Accounting Research as a research on behavior of accountants or on non-behavior of accountants influenced by accounting and reporting functions. Development of accounting practices undergoes so tremendously fast development, so that the role of research is required in order to give the input upon development of the accounting practices, particularly the one related to the behavioral accounting.

As a part of science of behavior, the theories of behavioral accounting are developed from empirical research upon human behaviors in organization. Therefore, the roles of research in development of science itself is undoubted any more. The scope of research in the field of behavioral accounting is very wide, not only covering the management accounting, but also covering the research in the fields of ethics, auditing, accounting system and financial accounting. The writing of this paper will converge on the role of research in the field of auditing.

There is something interesting to be viewed occurring in accountancy in general, and more particular in audit in the years 2000s whose influences are still able to be felt until this time. We need to remind anyone related to the accountant profession that $\mathrm{n}$ the years 2000s, some corporate financial scandalous cases were revealed to public, such as Enron, world Com and Lehman Brothers,

Unerman and O'Dwyer (2004) that year was the year identified by so many audit failures and also the accounting failures. Seemingly in those cases as if there were a "pattern", in which 'accountant' was always involved. The dimension of the created losses were so huge, therefore their occurrence not only shook the capital market, but had also caused the global monetary crisis and trust to the roles of accountant.

Such accounting cases had also motivated the US Government to issue the Sarbane Oxley Act in the year 2002 and PCAOB (Public Company Accounting Oversight Board). The issuance of Sarbane Oxley Act and PCAOB become so important in the world of accounting profession, especially the Public Accountant, namely the accountant profession which is fully self-regulated and becomes the state-regulated. In Indonesia, it also bears the same name, but its intensity and supervisory protocol 
are little bit different. The regulating practices are run by the OJK - Financial Service Authority applicable to the accountant profession having the foundation and following the thinking pattern similar to those run by $\mathrm{PCAOB}$, namely supervision and protection for Investors and supervision upon the activities of KAP - Public Accountant Office.

Reviewing the accounting problems, particularly some indicators, will be able to give a very large opportunity for the future researchers and possibly such research will give a very important contribution to accountants, especially the auditors to provide good audit quality.

In connection with a research in measuring the audit quality, some various kinds of independent variables have been used. Therefore, the research to be executed by the researcher will map the development of previous researches concerning with the audit quality.

\section{METHOD OF RESEARCH}

\subsection{Type of Research}

This is a descriptive research intended to describe the objective facts of a certain condition and offer the ideas for the next testing or research (Indriantoro and Supomo, 2002: 88). This research explains and describes history and development of measuring indicators of audit quality by using 'Meta Analytical Method'.

This research applies the literature survey technique (documentation) in order to get the data related to the audit quality. This documentation is conducted by means of collecting the journals from several previous researches on audit quality, commencing from the year 1981 till the year 2018 .

\section{OUTPUTS AND DISCUSSION}

\subsection{Data Analysis}

The researcher carries out the mapping on development and on measuring applied in this research, namely on the audit quality from the year 1981 until the year 2018. Such mapping is conducted by the researcher and produces a description concerning with development of researches on audit quality.

\section{Discussion and Output of Research}

Data analysis conducted by the researcher is able to give information concerning with variables applied to measure the audit quality. The research done by DeAngelo (1981), used the size of Auditor Office as variable of audit quality. DeAngelo (1981) declared that the audit quality given by the public accountant can be seen from the size of office of the public accountant performing the audit. A Big Public Accountant Office (Big 4 Accounting Firm) is believed to be able to perform a more qualified audit compared to a Small Public Accountant Office (Non-Big 4 Accounting Firm).

The next research is conducted by Deis Jr and Giroux (1992) the indicator set up to determine the audit quality is the duration of relation between auditor and the client (Audit Tenure) and Amount of Clients. The output of this research declares that the longer the auditor conducts an audit to the same client, the audit quality produced is getting lower and lower. The second output of the research is that the bigger amount of clients the auditor has, the audit quality given by the auditor will be better and better, because an auditor will maintain his/her reputation to the clients.

The research in the same year was conducted by Carcello, Hermanson et al. (1992) declaring that the variables determining the audit quality consisted of 41 (forty one) variables and concluded that there were only 4 (four) variables determining most on the establishment of audit quality. Those four variables are as follows: auditing experience, understanding on the Client's industry, being responsive to the client's needs, and the compliance of auditor to auditing regulations and to auditing standards.

Development of research for indicators in establishment of audit quality in the year 2003 was conducted by Wooten (2003) stating that the indicators setting up the establishment of audit quality were: reporting the errors of agency and those of the accounting system, good commitment, skeptics, and decision making. At the research done by Wooten (2003) stated that the audit quality is also determined by the detection on material misstatement and the report on material misstatements. Such reporting on material misstatement is determined by competence of the auditor.

The indicators building-up the establishment of audit quality are as follows: the presence of time pressure owned by the auditor, and the possibility of an auditor conducting an irresponsible action of 
reducing or decreasing the audit quality. This is supported by a research conducted by Coram, $\mathrm{Ng}$ et al. (2003) declaring that a limited time allocation can cause 63\% (sixty three percents) of Senior Auditors in Australia commit an action of reducing the audit quality, whereas parts of those Auditors perform the auditing tasks with low risks. The outputs of research conducted by Donnelly, Quirin et al. (2003) on the auditors of the Big 6 in Singapore indicated that 89\% (eighty nine percents) of auditors undergoing the time pressure were involved in action able to reduce the audit quality and the auditor performance. However, due to a competition among the Public Accountant Offices, this forces the auditors to improve and increase their performances much better. Thus, the auditors should be able to allocate their times precisely and able to determine the amount of audit fee and able to offer the audit fee precisely (Power 2003).

In the year 2004, the research conducted by Pierce and Sweeney (2004) confirmed that there was a decrease in performance of an auditor due to the factor of short-time auditing assignment he had, and even it was shorter than the time normally allocated for an assignment. The establishment of audit quality is different in every country as revealed by Khurana and Raman (2004) that a good audit quality by a public accountant office of the Big-4 only occurs in the United States. However, this does not occur in Australia, Canada and England. This is due to the factor related to litigation risk of the Public Account Office of the Big-4 as a bigger auditor in USA compared to those in other countries.

With regard to audit services, of course there are rewards given by the client to the auditor in the use of his services. Of course the fee is a material consideration by the auditor in carrying out his duties. The audit fee indicator becomes very important for the creation of audit quality this is revealed by Hoitash, Markelevich et al. (2007) when the auditor negotiates with the client about the amount of the fee to be paid by the client against the work of the auditing report, then it is likely reciprocal concessions will occur which will clearly reduce the quality of audit reports. This action clearly leads to actions that override professionalism, where reciprocal concessions will reduce the interest of safeguards over the quality of auditors.

In the same year, a research done by Carrera, Gómez-Aguilar et al. (2007) got an evidence from the output of their research that more than half of negotiation of the auditors and their clients can influence quality of auditing report. This is indirectly an unethical process of negotiation that will reduce the audit quality in the subject of financial statement of the client and the audit opinion issued.

Boon, McKinnon et al. (2008) found evidence that the existence of unethical negotiation behavior resulted in the results of negotiations in the form of financial statements that the results would be very predictable, in other words the results of negotiations would result in reciprocal consequences which at the end would lead to opinions which would be issued . Coram, Glavovic et al. (2008) found evidence in his research that in the negotiation process of auditors and clients based on standards that should be met from the Public Accounting Reporting Standards (SPAP), the possibility of negotiations that would be tough and training positions if they insisted on considering minimum standards based on SPAP. This is because the auditor is most likely to maintain continuity in getting clients. Such actions are certainly very contrary to audit professionalism.

The understanding on professional ethical codes and professional behavior become a special attention for the public accountant at present. In Indonesia, professional behavior becomes a very important attention in which it has become fundamental principle of professional ethics that must be obeyed practitioners. According to IAI - Association of Indonesian Accountants, such principles, namely integrity, objectivity, competence, accuracy, and professional carefulness, confidentiality as well as the professional behavior principle. In a research, it is found out that the ethical code is one of the principles establishing an audit quality. This research was conducted by Taringan and Bangun (2013) declaring that the ethics had positive and significant influences to the audit quality, in which the testing was done either simultaneously or partially. This means that the higher the ethic of an auditor is, the higher impact it gives to quality of its auditor.

In building up the audit quality of an auditor, apart from implementing his professional ethics, an auditor should be independent and competent in his field, or should understand about his assignment and even should have a specific specialization. This is assumed that the presence of specialization indicator will establish an audit quality. An auditor having a specialization will have a bigger possibility to detect an error and the deviations occurring at the financial statement, so that this will be 
able to help the Company provide better information (Mostafa Mohamed and Hussien Habib 2013). Specialization is a ability owned by someone in a certain field, so that capable of doing the work carefully and thoroughly compared to other persons having no specialization (Ishak, Perdana et al. 2015)

From the aforesaid statement, in the year 2018 there is a contradictory factor, namely the presence of Auditor Specialization. Such research was conducted by Sari (2018) declaring that the result of her research empirically gave evidence that the indicator of Auditor Specialization through the measurement of ownership of clients has a negative effect to the audit quality; while strategy of the client's business negatively influences the relation between the Auditor Specialization and Audit Quality. This occurs due to the presence of members of Auditor Specialization Team assuming bigger and more burden in their works. Therefore, in order to maintain the Auditor Quality, either KAP (Public Accountant Office) or the Regulator must determine or stipulate the optimum work load of each of its auditing members. The condition of over-work load will give an impact to the decrease of its auditing quality, so that the credibility of audit profession will finally be in question.

Apart from a discussion related to the research development by using the measuring indicators to the audit quality, the researcher obtains the result that by using the same measuring indicators will produce different research outputs.

The results obtained by researcher is that the indicator using time pressure in forming audit quality has different outputs as the research conducted by Power (2003) revealing that the existence of competition among the Public Accountant Offices will force the auditors to be able to allocate the time in their assignments, so that they can allocate their times to complete their auditing tasks. However, in the following year, a research done by Pierce and Sweeney (2004) stating that due to the short and limited time for auditor assignment had caused the decrease in performance resulting the decrease in their audit quality.

\section{CONCLUSIONS AND DisCusSion}

Based on the results of previous researches conducted from year to year on the Audit Quality by DeAngelo in the year 1981 till the research done in 2018 by Sari, they conclude that there are some indicators supporting the increase of audit quality.

Just like the application of ethical code that has already been specified well by auditors in doing their auditing assignment, the presence of such indicators give a guideline for the auditors that the application of such ethical codes give a trust to the users of financial statement or to community, that the tasks conducted by the auditors are really executed properly. Although an auditor is encountered by problem of time pressure, the auditor remains doing his job very well, so that the evaluation or assignment performed do not reduce the audit quality given.

The limitedness of this research is the analytical unit applied, namely the audit quality. This research is different from or not consistent with the result of research that will be possibly conducted by the next researchers. This is due to the different condition at the research place or phenomena related to the audit quality.

\section{REFERENCES}

[1] Boon, K., J. McKinnon, et al. (2008). "Audit service quality in compulsory audit tendering: Preparer perceptions and satisfaction." Accounting Research Journal 21(2): 93-122.

[2] Carcello, J. V., R. H. Hermanson, et al. (1992). "Audit quality attributes: The perceptions of audit partners, preparers, and financial statement users." Auditing 11(1): 1.

[3] Carrera, N., N. Gómez-Aguilar, et al. (2007). "Mandatory audit firm rotation in Spain: a policy that was never applied." Accounting, Auditing \& Accountability Journal 20(5): 671-701.

[4] Coram, P., J. Ng, et al. (2003). "A survey of time budget pressure and reduced audit quality among Australian auditors." Australian Accounting Review 13(29): 38-44.

[5] DeAngelo, L. E. (1981). "Auditor size and audit quality." Journal of accounting and economics 3(3): 183-199.

[6] Deis Jr, D. R. and G. A. Giroux (1992). "Determinants of audit quality in the public sector." Accounting Review: 462-479.

[7] Donnelly, D. P., J. J. Quirin, et al. (2003). "Auditor acceptance of dysfunctional audit behavior: An explanatory model using auditors' personal characteristics." Behavioral research in accounting 15(1): 87-110. 
[8] Hoitash, R., A. Markelevich, et al. (2007). "Auditor fees and audit quality." Managerial Auditing Journal 22(8): 761-786.

[9] Ishak, F. A. P., H. D. Perdana, et al. (2015). "Pengaruh Rotasi Audit, Workload, dan Spesialisasi Terhadap Kualitas Audit Pada Perusahaan Manufaktur Yang Terdaftar Di Bursa Efek Indonesia Pada Tahun 20092013." Jurnal Organisasi dan Manajemen 11(2): 183-194.

[10] Khurana, I. K. and K. Raman (2004). "Litigation risk and the financial reporting credibility of Big 4 versus non-Big 4 audits: Evidence from Anglo-American countries." The Accounting Review 79(2): 473-495.

[11] Mostafa Mohamed, D. and M. Hussien Habib (2013). "Auditor independence, audit quality and the mandatory auditor rotation in Egypt." Education, Business and Society: Contemporary Middle Eastern Issues 6(2): 116-144.

[12] Pierce, B. and B. Sweeney (2004). "Cost-quality conflict in audit firms: an empirical investigation." European Accounting Review 13(3): 415-441.

[13] Power, M. K. (2003). "Auditing and the production of legitimacy." Accounting, organizations and society 28(4): 379-394.

[14] Sari, D. K. (2018). "Audit Specialization and Audit Quality: The Role of Client's Business Strategy." KnE Social Sciences 3(11): 144-172.

[15] Taringan, M. U. and P. Bangun (2013). "Pengaruh Kompetensi, Etika, dan Fee Audit Terhadap Kualitas Audit." Akuntansi Krida Wacana 13(1).

[16] Unerman, J. and B. O’Dwyer (2004). "Enron, WorldCom, Andersen et al.: a challenge to modernity." Critical Perspectives on Accounting 15(6-7): 971-993.

[17] Wooten, T. C. (2003). "Research about audit quality." The CPA Journal 73(1): 48.

\section{AUTHORS' BIOGRAPHY}

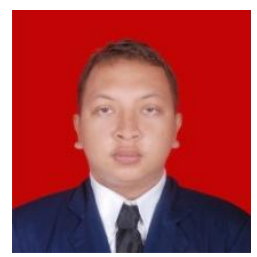

Muhammad Faris is an accounting master student in the faculty of economics and business at Airlangga University, Surabaya, Indonesia. interest in research in auditing related to audit quality, auditor ethics and the development of research in the audit field.

Citation: Mohammad Faris, Arsono Laksmana. "Development of Accounting Research in the Field of Auditing: Meta Analysis " International Journal of Managerial Studies and Research (IJMSR), vol 6, no. 12, 2018, pp. 26-30. doi: http://dx.doi.org/10.20431/2349-0349.0612004.

Copyright: () 2018 Authors. This is an open-access article distributed under the terms of the Creative Commons Attribution License, which permits unrestricted use, distribution, and reproduction in any medium, provided the original author and source are credited. 